\title{
Level changes of the Baltic Sea in the Holocene based on the study of lakes bottom sediments of the Karelian Isthmus
}

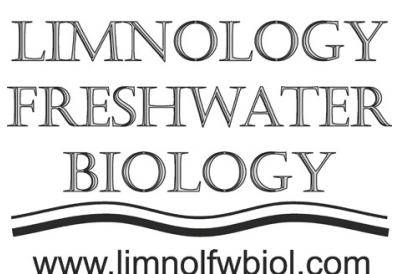

www.limnolfwbiol.com

\author{
Shatalova A.E. ${ }^{1 *}$, Kublitsky U.A. ${ }^{1}$, Subetto D.A. ${ }^{1}$, Rosentau A. ${ }^{2}$, Ludikova A.V. ${ }^{3}$, \\ Sokolova N.V. ${ }^{1}$, Syrykh L.S. ${ }^{1}$ \\ ${ }^{1}$ Herzen State Pedagogical University of Russia, Moika 48, St. Petersburg, 191186 Russia \\ ${ }^{2}$ The University of Tartu, Tartu, Estonia \\ ${ }^{3}$ Institute of Limnology, Russian Academy of Sciences, St. Petersburg, Russia
}

\begin{abstract}
In this study, we attempted to reconstruction of level changes of the Baltic Sea in the Holocene based on investigation of more than 30 sediment cores from bottom sediments of three lakes located on the Karelian Isthmus. It is mostly that there were one phase of Ancylus transgression and two phases of Litorina transgression. The low content of individual halophilic species, indicate that the lake was only slightly affected by saline waters, therefore the level of the Baltic Sea at that time was about $12 \mathrm{~m}$ higher than the present one.
\end{abstract}

Keywords: the Baltic Sea, the Holocene, diatoms, paleoreconstruction, Litorina transgression

\section{Introduction}

The dynamics of the Baltic sea level is of great interest to paleogeographers, because there are discussions about the transgressive-regressive phases of the sea and its influence on the coastal territories during the Holocene. To reconstruct the natural conditions a popular and reliable method of studying the bottom sediments of lakes was used. Actual objects for the study of transgressive cycles are lakes located near to the coastline at different hypsometric levels (Shatalova et al., 2018). The coastline of the Eastern part of the Gulf of Finland has been studied since the end of the 19th century. It was found that during the Holocene climate optimum, in the Atlantic period, the Litorina transgression had a significant impact on the coastal zone and surrounding landscapes, the age and number of phases of which are being discussed. According to studies of lake sediments on the coast of the Eastern part of the Gulf of Finland, Litorina transgression began around $8450 \mathrm{cal}$. BP. (Miettinen et al., 2007). The maximum level of transgression was observed in the range of 7600-6500 cal. BP. (Miettinen et al., 2007). Some authors also discriminate from two to six transgressive phases (Miettinen et al., 2007; Sandgren et al., 2004).

\section{Material and methods}

In the frame of this study selected 3 lakes located at different hypsometric levels in the North-Western part of the Karelian isthmus for a more accurate correlation in reconstructing the dynamics of transgressive-regressive cycles of the Baltic sea: Goluboye (12 m), Mozhevelnoye $(14 \mathrm{~m})$ and Trigorskoye $(16 \mathrm{~m})$. Sampling took place in October 2017 from a raft, using a Russian peat-corer. In total, more than 30 sediment cores were selected and described. Laboratory methodsinclude diatom, geochemical, palynological, chironomidae analyses and radiocarbon (AMS) Dating (Shatalova et al., 2018).

\section{Results}

In the early Holocene $(\sim 10700$ cal. BP) Lake Goluboye basin was flooded by the waters of Lake Ancylus. About 9700-9800 cal. BP was the regression of Lake Ancylus. However, in the depth range of 898$880 \mathrm{~cm}$, there is a sudden peak of species-indicators of increased salinity, which may indicate a short stage of the Mastogloia Sea. In the period 9800-9080 and 89607560 cal. BP Lake Goluboye was an isolated waterbasin. During the period of 7650-6025 cal. BP in the sediments of Lake Goluboye indicators of salinity are detected and this interval corresponds to the phase of Litorina transgression, but the lake was still fresh, therefore, the level of the Litorina Sea reached or slightly exceeded the level of the lake $(\sim 12 \mathrm{~m})$. After $6025 \mathrm{cal}$. BP content of halophilic taxa decreases that reflects the regression of the Litorina Sea and the isolation of the Goluboye Lake. After $4594 \mathrm{cal}$. BP on the periphery of the lake begins the process of peat formation andnatural conditions are approaching modern ones (Studie der Holozän, 2019). 


\section{Conclusions}

Thus, the stage of Ancylus transgression was identified, which is dated to $10100-9700 \mathrm{cal}$. BP. Also, diatom analysis allowed us to identify 2 phases of Litorina transgression. The beginning of the second phase was dated to 7570-7500 cal. BP, which corresponds to the maximum of transgression. The predominance of species that are indifferent to salinity, as well as the low content of individual halophilic species, indicates that the lake was only slightly affected by salty waters, so the level of the Baltic Sea at that time was higher than the modern by about $12 \mathrm{~m}$ (Studie der Holozän, 2019).

The study is supported by RFBR grant No 18-0580087 and by the President's grant № MK-5595.2018.5.

\section{References}

Miettinen A., Savelieva L., Subetto D. et al. 2007: Palaeoenvironment of the Karelian Isthmus, the easternmost part of the Gulf of Finland, during the Litorina Sea stage of the Baltic Sea history. Boreas 36:441-458.
Sandgren P., Subetto D.A., Berglund B.E. et al. 2004: Mid-Holocene Littorina Sea transgressions based on stratigraphic studies in coastal lakes of NW Russia. GFF 126:363-380.

Shatalova A., Kublitsky U., Subetto D. et al. 2018. Study of paleogeographic features of the northern part of the Karelian Isthmus during the Holocene. In: Materials of the 3rd international paleolimnological conference in Kazan, pp. 112.

Shatalova A.E., Kublitsky U.A., Subetto D.A. et al. 2018. The first results of paleogeographical studies of the northern part of the Karelian isthmus during the Holocene. In: International seminar "Geology, Geoecology, evolutionary geography", pp. 102.

Studie der Holozän - 2019. Veränderungen der Ostsee aufdem Territorium des Karelischen -Isthmus Feld symposium INQUA-PeriBaltic-Gruppe «Von der Weichselschen Eisplatten dynamic biszur Holozän - Landnutzungsentwicklung in Westpommern und Mecklenburg". 98-99 Wissenschaftlicher Technischer Bericht STR 19/01, Potsdam: GFZ Deutsches Geo Forschungs Zentrum. DOI: http://doi.org/10.2312/GFZ. b103-19012. 